\title{
GLOSY
}

\section{PAULINA WYSZYŃSKA-ŚLUFIŃSKA}

https://doi.org/10.33995/wu2019.1.6

\section{Glosa aprobująca}

\section{do Uchwały Sądu Najwyższego 7 sędziów}

z dnia 20 czerwca 2017 roku,

sygn. akt III CZP 114/16

[OSNC $2017 \mathrm{nr} 12$ poz. 130]

Teza:

Przepis art. 50 ust. 1 ustawy z dnia 22 maja 2003 roku o ubezpieczeniach obowiqzkowych, Ubezpieczeniowym Funduszu Gwarancyjnym i Polskim Biurze Ubezpieczycieli Komunikacyjnych [tekst jedn.: Dz. U. 2016, poz. 2060 z późn. zm.] ma zastosowanie do szkód wyrzqdzonych przez psa wykorzystywanego przez rolnika użytkowo w gospodarstwie rolnym.

1. Szkody wyrządzone przez psa wykorzystywanego przez rolnika prowadzącego gospodarstwo rolne nie są sprawami zdarzającymi się bardzo rzadko, na potwierdzenie czego można wskazać liczbę spraw rozpatrywanych przez sądy powszechne. 0 ile zdecydowanie częściej sądy przychylaja się do roszczeń powodów, nakazując zapłatę stosownego odszkodowania oraz zadośćuczynienia w ramach obowiązkowego ubezpieczenia odpowiedzialności cywilnej rolników z tytułu posiadania gospodarstwa rolnego, o tyle pojawiły się również przypadki oddalenia roszczeń. Komentowana uchwała w pewien sposób stanowi przewodnik nie tylko dla sądów rozpoznających te sprawy, lecz przede wszystkim dla poszkodowanych i ich pełnomocników: 1] w zakresie, w jakim należy kwalifikować szkodę wyrządzona przez psa oraz - w konsekwencji: 2) w jaki sposób przeprowadzić postępowanie dowodowe, aby roszczenie poszkodowanego zostało uwzględnione.

2. We wniosku z dnia 9 grudnia 2016 roku, sygn. akt RF 321/EK/16 Rzecznik Finansowy skierował do Sądu Najwyższego pytanie prawne o rozstrzygnięcie: „czy art. 50 ust 1. Ustawy z dnia 22 maja 2003 r. o ubezpieczeniach obowiązkowych, Ubezpieczeniowym Funduszu Gwarancyjnym 
i Polskim Biurze Ubezpieczycieli Komunikacyjnych ${ }^{1}$ (dalej: u.u.o.) ma zastosowanie do szkód powstałych przy udziale psa wykorzystywanego przez rolnika użytkowo w gospodarstwie rolnym". W uzasadnieniu wniosku Rzecznik wskazał na rozbieżności w orzecznictwie oraz w praktyce ubezpieczeniowej w zakresie kwalifikacji szkody wyrządzonej przez psa jako szkody pozostajacej w związku z posiadaniem gospodarstwa rolnego (a w konsekwencji podlegającej naprawieniu z obowiązkowego ubezpieczenia odpowiedzialności cywilnej rolników).

Rzecznik wskazał na ukonstytuowanie się dwóch przeciwstawnych stanowisk sądów powszechnych w powyższym zakresie. Pierwszy pogląd (mniejszościowy), opowiadający się za brakiem funkcjonalnego powiązania między wyrządzoną szkodą a posiadaniem gospodarstwa, spowodowany był kwalifikacja psa jako zwierzęcia domowego, a nie zwierzęcia gospodarskiego w myśl ustawy z dnia 27 czerwca 2009 roku. ${ }^{2}$ Taka kwalifikacja skutkowała oddaleniem roszczenia o naprawienie szkody z umowy ubezpieczenia odpowiedzialności cywilnej rolnika z uwagi na brak związku pomiędzy szkodą spowodowana przez psa wykorzystywanego w gospodarstwie rolnym a posiadaniem tego gospodarstwa. Rzecznik Finansowy we wniosku szeroko odwoływał się do uzasadnienia wyroku Sądu Apelacyjnego w Lublinie z dnia 13 stycznia 2015 roku. ${ }^{3}$ W wyroku tym (wskazywanym w orzeczeniach innych sądów powszechnych, oddalajacych roszczenie powodów) przy ocenie kwalifikacji psa sąd niewłaściwie odwołał się do pojęcia zwierzęcia gospodarskiego. Jednakże w mojej ocenie z uwagi na błędy natury procesowej, dotyczące prowadzenia postępowania dowodowego - powyższe uchybienie w zakresie prawa materialnego nie stanowiło wyłącznej przyczyny oddalenia roszczeń powodów. Należy zauważyć, że sąd apelacyjny wskazał, iż w toku postępowania apelacyjnego nie dostarczono „żadnych innych argumentów ani [...] innej roli (charakteru), z jaką wiąże się posiadanie tegoż zwierzęcia w gospodarstwie ubezpieczonej”. Powyższe stwierdzenie może świadczyć o 1) niewłaściwym przeprowadzeniu postępowania dowodowego, w tym zaniechaniu zgłoszenia wniosków dowodowych (lub ich nieprawidłowym sformułowaniu) przez strony, 2) braku przeprowadzenia dowodów przez sąd z urzędu, a w konsekwencji 3) o błędnej ocenie dowodów, dokonanej z naruszeniem art. 233 kodeksu postępowania cywilne$\mathrm{go}^{4}$, co w rezultacie mogło doprowadzić do rozstrzygnięcia niekorzystnego dla poszkodowanych. Niestety, do podobnej konkluzji prowadzi analiza przywoływanego przez rzecznika wyroku Sadu Rejonowego w Zambrowie z dnia 14 października 2013 roku. ${ }^{5}$ Sąd wprost orzekł, że powód nie wykazał, aby pies był wykorzystywany w prowadzonej działalności rolniczej. Pamiętać należy, że w prawie cywilnym, zgodnie z zasadą rozkładu ciężaru dowodowego (art. 6 kodeksu cywilnego, dalej: k.c. ${ }^{6}$ ], ${ }^{7}$ to do powodów należało wykazanie i udowodnienie, że szkoda wyrządzona przez psa pozostawała w związku funkcjonalnym z posiadaniem gospodarstwa. Orzeczenie sadu rejonowego zostało uchylone przez sąd II instancji, przy czym sąd ten ograniczył się jedynie do stwierdzenia,

1. Tekst jedn.: Dz. U. 2013, poz. 393 z późn. zm.

2. Ustawa z dnia 29 czerwca 2007 r. o organizacji hodowli i rozrodzie zwierząt gospodarskich (Dz. U. 2017, poz. 2132).

3. Wyrok Sądu Apelacyjnego w Lublinie z dnia 13 stycznia 2015 r., sygn. akt I ACA 656/14 LEX nr 164903.

4. Zob. art. 232 oraz 233 ustawy z dnia 17 listopada 1964 r. - Kodeks postępowania cywilnego (Dz. U. 2018, poz. 1360).

5. Wyrok Sadu Rejonowego w Zambrowie z dnia 14 października 2013 r., sygn. VI C 139/13.

6. Ustawa z dnia 23 kwietnia 1964 r. Kodeks cywilny (Dz. U. 2018, poz. 1025).

?. Na temat rozkładu ciężaru dowodowego zob. I. Adrych-Brzezińska, Ciężar dowodu w prawie i procesie cywilnym, Wolters Kluwer, Warszawa 2015. 
że szkoda wyrządzona przez psa pozostaje w związku z posiadaniem gospodarstwa, nie wyjaśniajac tego zagadnienia w sposób szczegółowy ${ }^{8}$.

Przeważające stanowisko judykatury, zaprezentowane we wniosku Rzecznika, opowiada się jednak za uznaniem odpowiedzialności ubezpieczyciela w razie wyrządzenia szkody przez psa wykorzystywanego użytkowo w gospodarstwie rolnym. W ocenie Rzecznika na aprobatę zasługiwało drugie z przytoczonych stanowisk, zgodnie z którym pies „stanowi element gospodarstwa rolnego", a więc istnieje związek funkcjonalny pomiędzy szkodą wyrządzoną przez psa a posiadaniem gospodarstwa rolnego. W komentowanej uchwale Sąd Najwyższy pozytywnie rozstrzygnał przytoczone pytanie prawne, co z pewnością będzie miało znaczenie dla praktyki ubezpieczeniowej w zakresie naprawienia szkody wyrządzonej przez psa wykorzystywanego użytkowo.

3. Odnosząc się do natury prawnej analizowanego problemu, oczywistym punktem wyjścia jest stwierdzenie, że odpowiedzialność ubezpieczyciela w ubezpieczeniach OC ma charakter odpowiedzialności akcesoryjnej, co oznacza, iż warunkiem wypłaty odszkodowania jest odpowiedzialność cywilna ubezpieczonego ${ }^{9}$. W uzasadnieniu glosowanego judykatu wskazano ogólne podstawy odpowiedzialności cywilnej za zwierzęta domowe oraz hodowlane (art. 431 k.c., gdy zwierzę działa z własnego popędu, jako lex specialis w stosunku do art. 415 k.c.). Zgodnie z normą prawną wynikająca z art. 50 u.u.o., przesłanką uzyskania odszkodowania jest wykazanie, iż szkoda powstała w związku z posiadaniem gospodarstwa przez rolnika. W celu dokonania prawidłowej wykładni przepisu artykułu 50 u.u.o., Sąd prawidłowo odwołał się do historii regulacji prawnych dotyczących ogólnych warunków obowiązkowego ubezpieczenia odpowiedzialności cywilnej rolników z tytułu prowadzenia gospodarstwa rolnego zawartych w aktach wykonawczych, obowiązujących przed dniem 1 stycznia 2004 roku. ${ }^{10}$ Sąd Najwyższy podkreślił znaczenie pojęcia „związku z posiadaniem gospodarstwa rolnego”, które to zastapiło poprzednio funkcjonujące pojęcie „związku z prowadzeniem gospodarstwa rolnego”. Pojęcie posiadania ma znaczenie znacznie szersze od pojęcia prowadzenia, bowiem posiadanie - w przeciwieństwie do prowadzenia obejmuje nie tylko działanie rolnika, lecz także skutki jego zaniechań. ${ }^{11}$ Odwołanie się przez Sąd Najwyższy do pierwotnych regulacji w zakresie ubezpieczenia odpowiedzialności cywilnej rolnika oraz innych podmiotów, za które ponosi on odpowiedzialność, służy podkreśleniu wagi kryterium podmiotowo-funkcjonalnego, warunkującego odpowiedzialność ubezpieczyciela. Wskazać należy, że w przypadku stosowania art. 50. u.u.o. wymagany jest związek funkcjonalny pomiędzy posiadaniem gospodarstwa rolnego a zdarzeniem powodującym szkodę (zamiast „związku przyczynowego zdarzenia sprawczego z prowadzeniem gospodarstwa"). Na poparcie tego stanowiska Sąd Najwyższy wskazał ugruntowaną już linię orzeczniczą co do pojęcia związku funkcjonalnego. Pogląd ten nie budzi wạtpliwości.

8. Wyrok Sądu Okręgowego w Łomży z dnia 24 września 2014 r., sygn. akt I Ca 122/14, LEX nr 1845888.

9. E. Kowalewski, Prawo ubezpieczeń gospodarczych, Oficyna Wydawnicza Branta, Bydgoszcz-Toruń 2002, s. 269.

10. Zob. §9 Rozporządzenia Ministra Finansów z dnia 30 grudnia 1993 r. w sprawie ogólnych warunków obowiązkowego ubezpieczenia odpowiedzialności cywilnej rolników z tytułu prowadzenia gospodarstwa rolnego (Dz.U. nr 134, poz. 653 z późn. zm.), a także wcześniejsze Rozporządzenie Ministra Finansów z dnia 18 grudnia 1990 r. w sprawie ogólnych warunków obowiązkowego ubezpieczenia odpowiedzialności cywilnej rolników z tytułu prowadzenia gospodarstwa rolnego (Dz. U. nr 89, poz. 526 z późn. zm.).

11. Zob. także wyrok Sądu Najwyższego z dnia 24 stycznia 2017 r., sygn. akt V CSK 163/16, LEX nr 2278326. 
4. Związek funkcjonalny musi istnieć pomiędzy szkodą a posiadaniem gospodarstwa. Ustawa o ubezpieczeniach obowiązkowych, w art. 2 ust. 1 pkt 4 nie definiuje pojęcia gospodarstwa rolnego w sposób wyczerpujący ani nie zawiera expressis verbis wyłączeń przedmiotowych w zakresie składników wchodzących w jego skład. Wydaje się, iż było to również powodem niewłaściwego stosowania art. 50 w kontekście analizowanego problemu przez sądy powszechne. Usprawiedliwione i konieczne jest więc uzupełnienie definicji legalnej przez posiłkowanie się normą prawną wynikająca z artykułu $55^{3}$ kodeksu cywilnego. Zgodnie z treścią tego artykułu poprzez gospodarstwo rolne należy rozumieć ogół czynników majątkowych, tworzących zorganizowaną całość, umożliwiająca wykonywanie działalności rolniczej (gospodarstwo rolne w ujęciu przedmiotowo-funkcjonalnym) ${ }^{12}$. W przedmiocie dotyczącym kwalifikacji psa jako składnika gospodarstwa rolnego każdorazowo należy badać czy pies - jako inwentarz żywy - jest wykorzystywany w celu prowadzenia działalności rolnika. Podkreślić należy, że wymagane jest przeprowadzenie szczegółowej analizy stanu faktycznego w zakresie ustalenia roli psa. Oznacza to, że nie w każdym przypadku pies należący do rolnika będzie wchodził w skład gospodarstwa rolnego, jednakże każdorazowo decydujące znaczenie będzie miał stan faktyczny w danej sprawie. W stosunkach wiejskich często pies ma spełniać rolę użytkową. W przypadku gdy zostanie wykazane, że pies jest wykorzystywany w pasterstwie lub że jest niezbędny do funkcjonowania gospodarstwa rolnego, ponieważ spełnia rolę użytkowa polegająca m.in. na pilnowaniu mienia wykorzystywanego do prowadzenia działalności rolniczej, pilnowaniu siedliska, zapewnieniu bezpieczeństwa, wówczas możliwe będzie przypisanie zwierzęciu cech psa pasterskiego lub stróżującego. W rezultacie pies będzie stanowił składnik gospodarstwa rolnego, co przesądzać będzie o występowaniu związku między wyrządzoną przez niego szkodą a prowadzeniem gospodarstwa (a nie tylko związku z posiadaniem posiadłości tak jak stwierdził Sąd Apelacyjny w Lublinie ${ }^{13}$ - argumentując, iż pies wykonywał jedynie taką funkcję, jaką pełni pies pilnujacy zwykłej posesji). Z drugiej strony, gdy pies nie spełnia funkcji użytkowej, np. jeśli jest to domowy pies do towarzystwa lub pies myśliwski, wykorzystywany w celu wykonywania swojego hobby, wówczas zwierzę takie nie mieści się w ramach dyspozycji art $55^{3}$ k.c., a w konsekwencji szkoda wyrządzona z jego udziałem przekroczy ramy art. 50 u.u.o. Zgodnie z rozkładem ciężaru dowodowego (art. 6 k.c.) konieczne będzie in casu, z uwzględnieniem okoliczności faktycznych danej sprawy, ustalenie roli psa występującego w gospodarstwie rolnym (niewykluczone, że pies będzie zarówno psem wykorzystywanym użytkowo, jak i psem do towarzystwa, w takim przypadku konieczne będzie ustalenie faktycznej przeważającej roli psa). Należy zgodzić się z Sądem Najwyższym, że brak przesłanki uznania psa za zwierzę gospodarskie w rozumieniu art. 2 ustawy o hodowli i rozrodzie zwierząt gospodarskich jest irrelewantne dla oceny, czy stanowi on składnik gospodarstwa rolnego (ustawa ta reguluje odmienny wycinek prowadzenia działalności rolniczej i w analizowanym przypadku nie ma znaczenia dla dokonania wykładni art. 50 u.u.o.). Należy zanegować stanowisko wyrażane przez niektóre sądy powszechne, że ustawa ustawa o hodowli i rozrodzie zwierząt gospodarskich przesądza o niemożności kwalifikacji psa jako składnika gospodarstwa rolnego.

12. D. Łobos-Kotowska, Art. 55³ k.c., [w:] Kodeks cywilny. Komentarz. Tom I. Część ogólna (art. 1-125), [red.] M. Fras, M. Habdas, Wolters Kluwer, Warszawa 2018/LEX.

13. Wyrok Sądu Apelacyjnego w Lublinie z dnia 13 stycznia 2015 r. op. cit. 
5. Wskazać należy, iż Sąd Najwyższy w sposób klarowny i wyczerpujący dokonał wykładni przytoczonego w tezie komentowanej uchwały artykułu w kontekście szkody wyrządzonej przez psa. Taka wykładnia jest zgodna z założeniami aksjologicznymi w zakresie funkcji ubezpieczeń obowiązkowych, jaką jest ochrona osób poszkodowanych. ${ }^{14}$ Szkody, jakie może wyrządzić pies, moga być dotkliwe w skutkach dla poszkodowanych, w szczególności w zakresie szkody na osobie. W takich sytuacjach skorzystanie z przyznanej przez prawo actio directa umożliwi wypłatę należnych świadczeń przez ubezpieczyciela zamiast rolnika (osoby pozostającej z nim we wspólnym gospodarstwie domowym lub osoby pracujacej w gospodarstwie rolnym], co będzie miało szczególnie znaczenie w przypadku, gdy rozmiar szkody uniemożliwiałby jej naprawienie z majatku osoby zobowiązanej do jej naprawienia.

6. Reasumując: należy zaaprobować przyjęty przez Sąd Najwyższy pogląd wyrażony w komentowanej uchwale. Brak jest przesłanek uzależniających możliwość zakwalifikowania psa jako zwierzęcia gospodarskiego w rozumieniu ustawy o organizacji hodowli i rozrodzie zwierzạt gospodarskich. Niemniej jednak podjęta uchwała nie przesądza o tym, że art. 50 ust. 1 u.u.o. będzie miał zawsze zastosowanie do szkód wyrzạdzonych przez psa wykorzystywanego przez rolnika. Decydujące znaczenie będzie miało prawidłowe ustalenie, że pies ten jest wykorzystywany użytkowo w gospodarstwie, przez co możliwe będzie wykazanie związku funkcjonalnego między powstałą szkodą a posiadaniem gospodarstwa.

\section{Wykaz źródeł}

Adrych-Brzezińska I., Ciężar dowodu w prawie i procesie cywilnym, Wolters Kluwer, Warszawa 2015. Kowalewski E., Prawo ubezpieczeń gospodarczych, Oficyna Wydawnicza Branta, BydgoszczToruń 2002.

Orlicki M., Ubezpieczenia obowiqzkowe, Wolters Kluwer, Warszawa 2011.

\section{Commentary on Supreme Court resolution of $20^{\text {th }}$ June 2017, case no. III CZP 114/14 (OSNC 2017 no 12, 130), adopted by 7 judges - on the damage caused by a dog used by a farmer on the agricultural farm in the light of the article 50 para. 1 of the compulsory liability insurance, Polish Guarantee Fund and Polish Motor Insurers' Bureau act}

The purpose of this article is to comment on the Supreme Court resolution dated $20^{\text {th }}$ June 2017, case no. III CZP 114/16 (OSNC 2017 no 12, 130) and adopted by 7 judges. This resolution addresses whether article no. 50 of the Act on compulsory liability insurance, Polish Guarantee Fund and Polish Motor Insurers' Bureau should be applicable to the damage caused by a dog used by a farmer. In the author's view, the Supreme Court properly indicated, that if the circumstances of the case are such that

14. Odnośnie funkcji ubezpieczeń obowiązkowych zob. M. Orlicki, Ubezpieczenia obowiqzkowe, Wolters Kluwer, Warszawa 2011, s. 169 i nast. 
there is sufficient evidence, to show that the dog would be considered as an element of the agricultural farm, then as a result and there is a link between the damage and the possession of the agricultural farm - and as a consequence the insurer, following the duty derived from art no. 50, must compensate for the damage.

MGR PAULINA WYSZYŃSKA-ŚLUFIŃSKA - asystent w Katedrze Prawa Cywilnego, Wydział Prawa i Administracji, Uniwersytet Gdański, radca prawny przy OIRP w Gdańsku.

e-mail: paulina.wyszynska-slufinska@ug.edu.pl https://orcid.org/0000-0002-7468-3639 